\title{
RETRACTED ARTICLE: On Comparing the Performance of Swarm-Based Algorithms with Human-Based Algorithm for Nonlinear Systems
}

\author{
Vishal Srivastava $^{1} \cdot$ Smriti Srivastava ${ }^{2} \cdot$ Gopal Chaudhary $^{3} \cdot$ Xiomarah Guzmán-Guzmán $^{4} \cdot$ Vicente García-Díaz $^{4}$ (i)
}

Received: 24 March 2021 / Accepted: 28 July 2021 / Published online: 24 August 2021

(c) The Author(s) 2021

The Editor-in-Chief and the publisher have retracted this article. The article was submitted to be part of a guest-edited issue. An investigation by the publisher found a number of articles, including this one, with a number of concerns, including but not limited to compromised editorial handling and peer review process, inappropriate or irrelevant references or not being in scope of the journal or guest-edited issue. Based on the investigation's findings the Editor-inChief therefore no longer has confidence in the results and conclusions of this article.

Author Smriti Srivastava has stated on behalf of all authors that they disagree with this retraction.
Supplementary Information The online version contains supplementary material available at https://doi.org/10.1007/s13369-021-06026-3

Open Access This article is licensed under a Creative Commons Attribution 4.0 International License, which permits use, sharing, adaptation, distribution and reproduction in any medium or format, as long as you give appropriate credit to the original author(s) and the source, provide a link to the Creative Commons licence, and indicate if changes were made. The images or other third party material in this article are included in the article's Creative Commons licence, unless indicated otherwise in a credit line to the material. If material is not included in the article's Creative Commons licence and your intended use is not permitted by statutory regulation or exceeds the permitted use, you will need to obtain permission directly from the copyright holder. To view a copy of this licence, visit http://creativecommons.org/licenses/by/4.0/.

Vicente García-Díaz

garciavicente@uniovi.es

Vishal Srivastava

vishal.srivastava0708@gmail.com

Smriti Srivastava

smriti@nsut.ac.in

Gopal Chaudhary

gopal.chaudhary88@gmail.com

Xiomarah Guzmán-Guzmán

UO273217@uniovi.es

1 Netaji Subhas Institute of Technology, Sector 3, Dwarka, New Delhi, India

2 Netaji Subhas University of Technology (Erstwhile NSIT), Sector 3, Dwarka, New Delhi, India

3 BharatiVidyapeeth's College of Engineering, Paschim Vihar, Delhi, India

4 Department of Computer Science, University of Oviedo, Oviedo, Spain 